\title{
ASSESSMENT OF THE MULTI FUNCTIONALITY OF A SMALL HYDROPOWER PROJECT AT PADHU KHOLA, KASKI, NEPAL
}

\author{
Achyut Bhandari ${ }^{1}$, Keshav Basnet ${ }^{1{ }^{*}}$, Nisha Pokharel $^{1}$, Kishor Kumar Shrestha ${ }^{1}$, and Nirmal \\ Prasad Baral ${ }^{1}$ \\ ${ }^{1}$ Infrastructure Engineering and Management Program, Department of Civil and Geomatics \\ Engineering, Pashchimanchal Campus, Institute of Engineering, Tribhuvan University, Nepal \\ *E-mail: basnet.keshav@gmail.com, ORCID 0000-0001-8145-9654
}

\begin{abstract}
Nepal has not utilized the potential of the water resources to the full extent. Systematic and wise development of such resources is of paramount importance for enjoying the maximum possible benefits. This study focused on the needs, challenges, and opportunities of new multifunctional small hydropower projects in Nepal. This study on Padhu Khola shows the possibility of incorporating other facilities along with hydropower for the locality's socio-economic development. The selection of the best layout of the hydropower generation and distribution of other hydropower components showed that the stream Padhu Khola had a power potential of $1 \mathrm{MW}$. The economic analysis resulted in the benefit-cost ratio of freshwater aquaculture, drinking water plants to be 1.98 and 1.97 respectively. Other facilities like forestry, local employment facilities, and tourism development were found feasible and practicable.
\end{abstract}

\section{Keywords}

Hydropower development, multipurpose hydropower, rural hydropower project, economic development.

\section{Introduction}

Nepal, being situated in the lap of the Himalayas and blessed with numerous perennial rivers in the hilly region, has ample opportunities for hydro energy production. The small catchment area and high cost associated with reserving the water in the hilly region can strengthen the concept of small hydropower plants in the locality. In many parts of the region, such streams are the only source of water for the livelihood. To address the social and economic development of the area, multipurpose projects like small hydropower can be one of the best alternatives in such regions (International Hydropower Association, 2018).

A multipurpose project targets the overall utilization of resources without focusing on only one benefit, but brings out all the possible benefits in an integrated way. In the context of developing nations like Nepal, with low figures of expenses, multipurpose projects support different infrastructural development, including hydropower. Multipurpose developments can make planning and operating hydropower more complicated, but also increased planning efforts may avoid a lot of problems caused by 
future unregulated uses of water. In conjunction with hydroelectric power generation, water can be used for irrigation, flood control, drinking water, domestic, municipal and industrial use, navigation, fishing, tourism, and other leisure activities. When the sources of the water are limited, and its necessity increases for different purposes, then the conflict arises. These kinds of disputes bolster up on water resources when a project tries to alter the existing water use in the area. Such disputes can be solved by adequately managing water for different purposes as in small hydropower project plants. Many already constructed single-purpose projects have occupied sites that could have been used for multipurpose project and thereby providing optimum uses of the available water. A multipurpose small hydropower project addresses the basic need of water of the locality as well as helps to strengthen the economic development due to increased economic and environmental features (Buras, 1982; Small Hydropower Promotion Project (SHPP/GTZ); Mini-Grid Support Programme (MGSP/AEPCESAP), 2004).

\section{Materials and Methods}

\subsection{Study Area}

The study area selected in this study was Parche village, Madi Gaupalika, Kaski district, Nepal (Figure 1). It is surrounded by Sikles village in the north, Tanting village in the east, Sardi Khola in the west and Sildujure in the south. The project site can be accessed by the road linking Pokhara and Shaudha, lying at about 13 $\mathrm{km}$ from Pokhara. Figure 2 shows the streams that contribute to the Padhu Khola. The Padhu Khola Hydropower Project was proposed in Padhu Khola (a perennial source of water) that converges to the Madi River (Figure 3) near
Tanting village with its major catchment area in Parche (Basnet et al., 2019).

The presentstudy on thePadhu Khola convinced the feasibility of the small hydropower plant of about $1 \mathrm{MW}$ in the region (Table 1). However, this pre-feasibility study showed that economic development can be enhanced in the community if the project is made multipurpose, including the major facilities like drinking water plant, freshwater aquaculture, tourism development, and small-scale hydropower. This study helps identify the available resources of the location and assists in determining the feasibility of multipurpose project at that location.

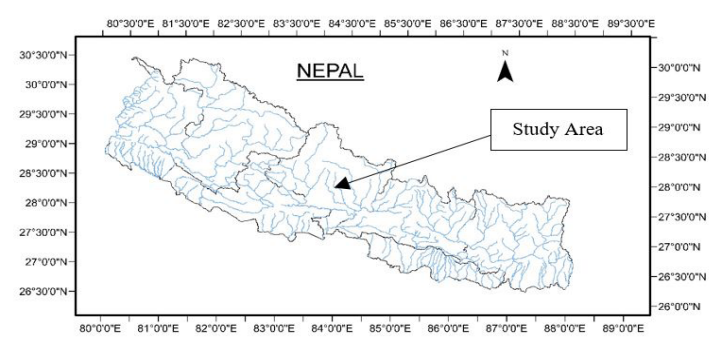

(a)

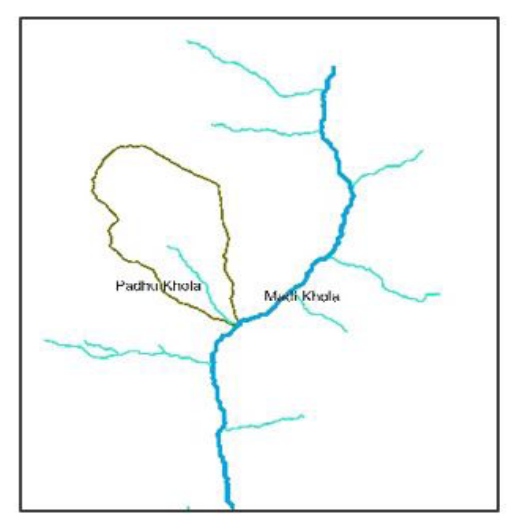

(b)

Figure 1: (a) Map of Nepal with the river system; and (b) Padhu Khola draining into Madi Khola 


\section{Nepal Engineers' Association, Gandaki}

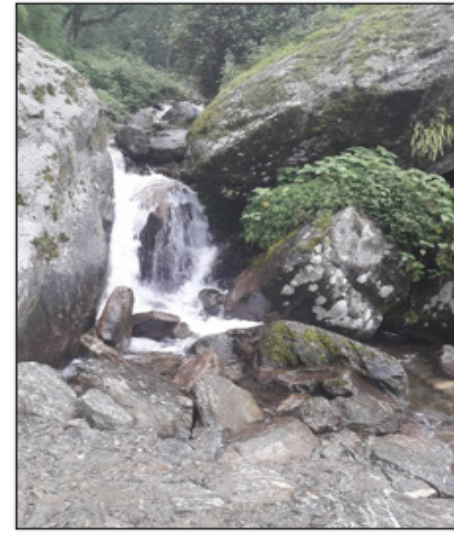

(a)

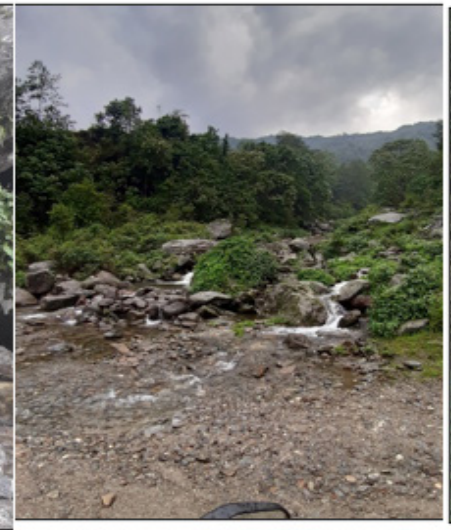

(b)

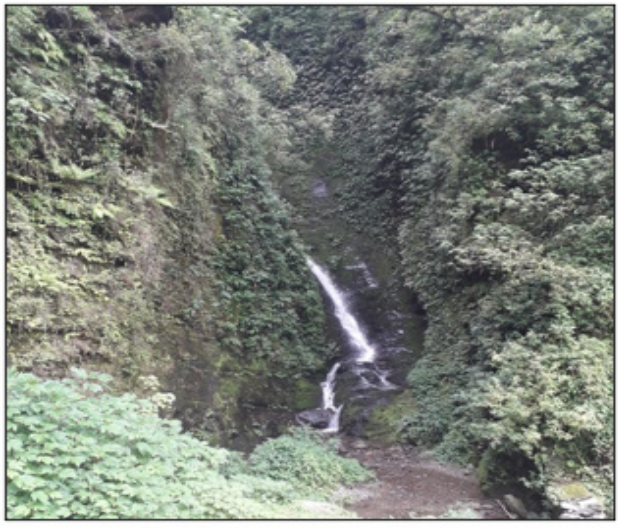

(c)

Figure 2: (a), (b) and (c) Streams contributing to Padhu Khola

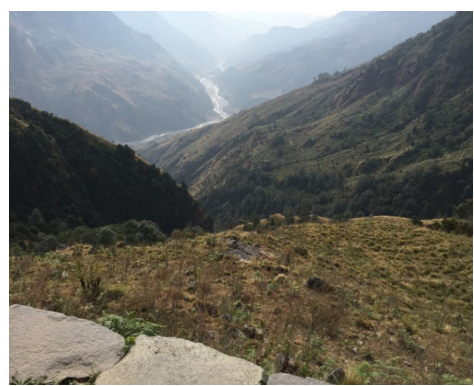

Figure 3: Madi Khola seen from the Parche

Village (study catchment area)

Table 1: Salient features of the Padhu Khola hydropower from the study

\begin{tabular}{|c|l|l|}
\hline \multicolumn{1}{|c|}{ 1. } & Location & \\
\hline (i) & Entire area & Madi \\
\hline (ii) & District & Kaski \\
\hline (iii) & Block & Madi \\
\hline (iv) & Village & Parche \\
\hline (v) & $\begin{array}{l}\text { Access-road From the } \\
\text { nearest airport - Pokhara }\end{array}$ & $\begin{array}{l}20 \mathrm{~km} \mathrm{from} \\
\text { Karuwa } 60 \mathrm{~km}\end{array}$ \\
\hline (vii) & Altitude & $1500 \mathrm{masl}$ \\
\hline (viii) & Head & $420.000 \mathrm{~m}$ \\
\hline (ix) & Discharge (45\% exceedance) & $0.30 \mathrm{~m}^{3} / \mathrm{s}$ \\
\hline (x) & Power & $1 \mathrm{MW}$ \\
\hline 2. & River Catchment & \\
\hline (i) & Catchment & $8.37 \mathrm{sq} . \mathrm{km}$. \\
\hline (ii) & Name of River & Padhu Khola \\
\hline
\end{tabular}

\subsection{Sector-wise Study}

\subsubsection{Desk Study and Reconnaissance}

As Padhu Khola is ungauged, different Methods like the Medium Irrigation Project (MIP) method, Water and Energy Commission Secretariat (WECS) method, and the Catchment Area Ratio (CAR) Methods were used to determine the stream's flow duration curve. The MIP method determines the average monthly runoff in the area with its seven categorizations in Nepal. The WECS method estimates the low flow, long term flow and flash flow based on the area and its altitude levels. The CAR method determines the flow in the stream assuming the given catchment is hydrologically similar to the gauged station used. Here, the Madi catchment was used to determine the flow in the Padhu catchment using the CAR method.

The MIP Methods and WECS Methods are the empirical Methods that estimate the flow based on the topography and altitude of the catchment. The CAR method predicts the flow based on the available gauged station hence is more accurate. Figure 4 describes the flow duration curve of the Padhu catchment calculated from all 3 Methods of discharge estimation Methods. 
The discharges calculated from the three different Methods were; 0.3295, 0.3147, and $0.302 \mathrm{~m}^{3} / \mathrm{sec}$, respectively. Although Padhu Khola (drainage area- $8.34 \mathrm{Km}^{2}$ ) is ungauged, it has several similar catchment characteristics with Madi river (drainage area- 1124 km²; (SOHAM, Nepal)) which has three cascading hydropower projects and is gauged too (Basnet et al. (2018). On that basis, CAR method was preferred for discharge calculation. Figure 4 shows the availability of water in the river throughout a year for hydropower production. Basnet et al. (2018) studied the possible layouts for hydropower generation in the area based on the topographic, geological and hydraulic constraints, benefit, and cost. Although layout 1 had high head, it had low discharge and in layout 2 despite intermediate discharge and head, the layout run through private property whereas, layout 3 had maximum discharge and intermediate head. Hence, with primary objective of maximization of economic benefit layout 3 was chosen with the components - weir, intake, and settling basin (Figure 6). The head in the selected layout would be 420 meters, and the discharge for $45 \%$ exceedance would be $0.3 \mathrm{~m}^{3} / \mathrm{sec}$.

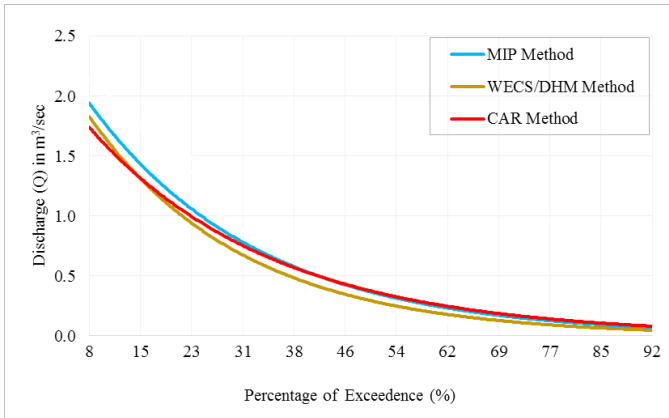

Figure 4: Flow duration curve of the Padhu Khola catchment
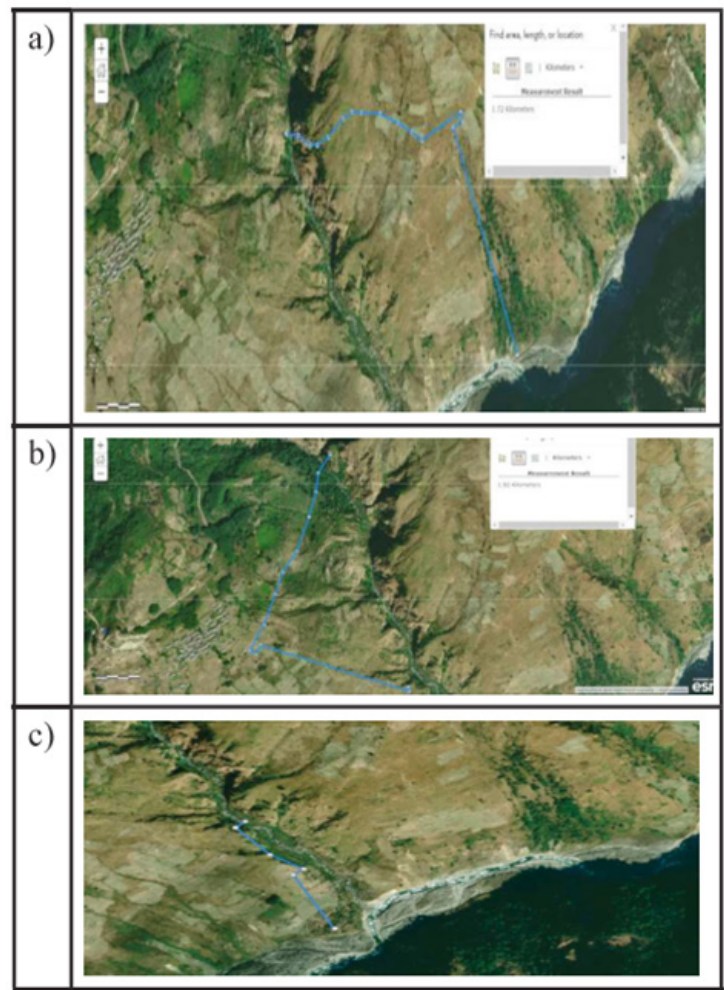

Figure 5: Possible layouts for hydropower in Padhu Khola (Basnet et al., 2018)

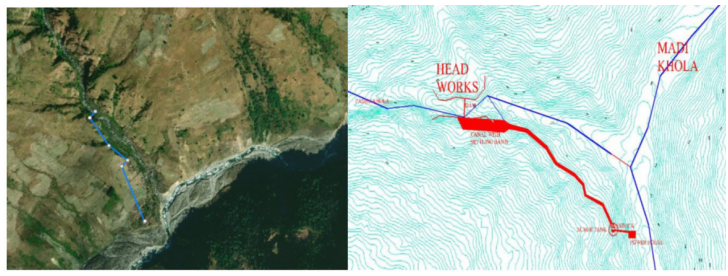

Figure 6: Best possible layout for potential hydropower at Padhu Khola (Basnet et al., 2018) In the site reconnaissance, the socio-economic problems over the area that could be solved by the management of water resources were considered along with the field validation for desk study. Problems being faced by the public and their suggestions were considered in the study. Incorporating the infrastructures to address all those problems separately requires high investment; hence to form a most optimum solution, the feasibility of all other facilities is to 
Nepal Engineers' Association, Gandaki be checked integrating the use of the same water for all other facilities. The preliminary stage would be the pre-feasibility check, followed by the formation of an optimum function to find the best integrated water management solution of the small areas like Padhu Khola. The prefeasibility of different facilities was checked with the aid of a checklist made incorporating different possible solutions of the combined water use management. It included all the available features as irrigation, drinking water, flood control, aquaculture, etc.

\subsection{Checklist Interpretation}

The output of the checklist was evaluated for a feasibility check for multipurpose projects. It justified the feasibility of freshwater aquaculture, water supply plant, forestry, floriculture, and recreation services. A priority list was made based on the need and feasibility for the area, interpreting the checklist filled (Table 2).

Table 2: Priority list of multipurpose facilities in Padhu Khola

\begin{tabular}{|l|l|}
\hline Rank & Facilities \\
\hline 1 & Freshwater aquaculture \\
\hline 2 & Drinking water \\
\hline 3 & Flood control \\
\hline 4 & Industries/ Employment generation \\
\hline 5 & Forestry and Wildlife management \\
\hline 6 & Irrigation \\
\hline 7 & Landslide management \\
\hline 8 & Recreation \\
\hline
\end{tabular}

The detailed and systematic studies of benefits and costs for different facilities to be provided and the inclusion or exclusion of each of the several purposes with the original single purpose project must be made in order to obtain this optimum socio-economic balance.
Basically, the design of any multipurpose project is an economic challenge. The structural features (dams, spillways, sluiceways, gates, water conductors, power plants, etc.) are the same for a single purpose and multipurpose projects. The most crucial point in multipurpose design is selecting the physical works and an operation plan to provide effective coordination and reconciliation among the various uses.

\subsection{Categorized Study for Different Purposes}

\subsubsection{Fisheries (Aquaculture)}

On the study of the locality and the types of fishes found nearby in similar streams, there is a huge potential for commercial aqua farming and fisheries. The commercial farming on similar catchments in other streams nearby also raises the possibility for environmental suitability of the fish farming in the area.

Upon interviewing the villagers of the Parche village, the local people seemed interested in aquaculture. According to the farmers, they cannot produce enough trout for the market, and consumers come directly to their farms to buy. There is no obligation to transport the fish to the market. Often the fishes are sold even before a standard market size is reached. These are clear indications that there is a potential domestic market of a considerable size to be exploited. The village not being much far from Pokhara, is also a famous tourist destination. Hence, there is a high demand of fish for tourists for the sole purpose of consumption too. During the site visit, an existing fish pond was explored that used the Padhu Khola as the water source (Figure 7).The ongoing fish production farming in the area showed the climate suitability in the area. With larger reservoir capacity for the hydropower generation, the scale of fish 
farming and its production can be increased parallel.

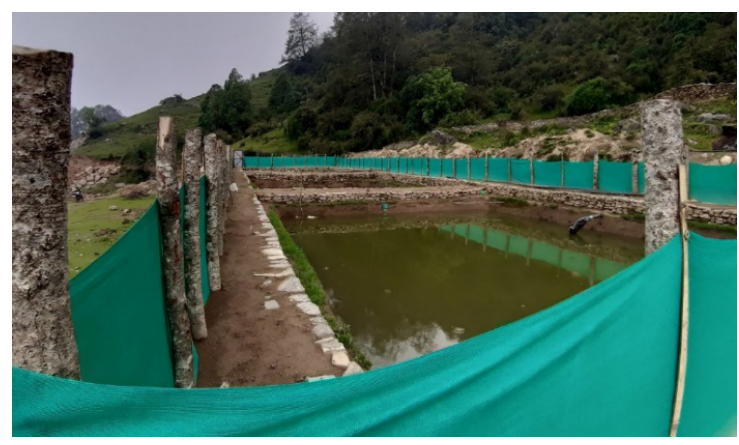

Figure 7: Fresh aquaculture pond on Parche

$$
\text { village }
$$

Manmade reservoirs will collect rich nutrients from the villages and farms during rainfall, which will promote plankton growth and the potential for the development of planktivorous fish culture. As this occurs, new jobopportunities will be created for the local people from the community around the reservoir. At the same time, national fish production and per capita fish protein consumption will also increase. Poverty can be reduced, and food security improved when farmers and subsistence fishers achieve higher levels of sustainable productivity.

\subsubsection{Economic Analysis}

Sharma et al. (2018) calculated the total cost of fish production by summing total variable cost (TVC) and total fixed cost (TFC) incurred in the production process. Considering the inflation rate of May 2020 to be $5.8 \%$, the approximate cost of fish production per ha of the pond per year would be NRs. 7,56,113.60. The cost incurred for fingerlings, feed, energy cum fuel, manure cum fertilizers, labor (including hired and family labor), maintenance cost, lime, and other costs were considered variable costs. Whereas the expenses on land rent, interest payment and depreciation of farm tools and machinery were included under fixed cost.

\subsubsection{Drinking Water}

As there is no immediate demand for drinking water in the local village, the study was done if the water could be transported on drinking water bottles to the nearby market place. In the process, the tests on the quality of the water, market analysis, and financial analysis were done to determine the feasibility of developing of drinking water plant in the water system. Table 3 shows that water quality is useable for drinking water after some treatment and frequent evaluation and is within WHO drinking water standards.

Table 3: Lab test results of the study on quality of water

\begin{tabular}{|c|c|c|}
\hline Tests & Objective & Result \\
\hline \multicolumn{3}{|c|}{ Physical Test } \\
\hline $\begin{array}{l}\text { Turbidity } \\
\text { Test }\end{array}$ & $\begin{array}{l}\text { To determine } \\
\text { the murkiness of } \\
\text { the water. }\end{array}$ & $\begin{array}{l}\text { Nil. NTU value } \\
\text { was obtained, } \\
\text { showing clear } \\
\text { water without } \\
\text { turbidity. }\end{array}$ \\
\hline \multicolumn{3}{|c|}{ Biological test } \\
\hline $\begin{array}{l}\text { Coliform } \\
\text { Bacteria } \\
\text { test }\end{array}$ & $\begin{array}{l}\text { To determine } \\
\text { the presence of } \\
\text { microbiological } \\
\text { pollution in } \\
\text { water. }\end{array}$ & $\begin{array}{l}\text { Absence of } \\
\text { coliform bacteria } \\
\text { showing no } \\
\text { pollution by } \\
\text { human waste. }\end{array}$ \\
\hline \multicolumn{3}{|c|}{ Chemical Test } \\
\hline $\begin{array}{l}\text { Chlorine } \\
\text { Test }\end{array}$ & $\begin{array}{l}\text { To determine } \\
\text { the presence of } \\
\text { chlorine in the } \\
\text { water. }\end{array}$ & $\begin{array}{l}\text { Absence of } \\
\text { chlorine in the } \\
\text { water. }\end{array}$ \\
\hline pH Test & $\begin{array}{l}\text { To know } \\
\text { the acidity/ } \\
\text { alkalinity of } \\
\text { water. }\end{array}$ & $\begin{array}{l}\text { The pH value } \\
(7.5) \text { was within } \\
\text { a tolerable range } \\
\text { of standards. }\end{array}$ \\
\hline
\end{tabular}

(Source: Pashchimanchal Campus, 2018)

On a local focus group interaction, no immediate 
Nepal Engineers' Association, Gandaki emergency for drinking water service was observed. But due to the increasing demand for bottled mineral water, the feasibility of the production of mineral water at a commercial level, economic analysis for drinking water plants was made.

\subsubsection{Economic Analysis}

There is increasing preference of bottled mineral water to tap water in cities these days. Also, easy route to nearby market gives likelihood of drinking water plants in the location. Economic analysis was performed considering the major components of the water treatment plant (Figure 8).

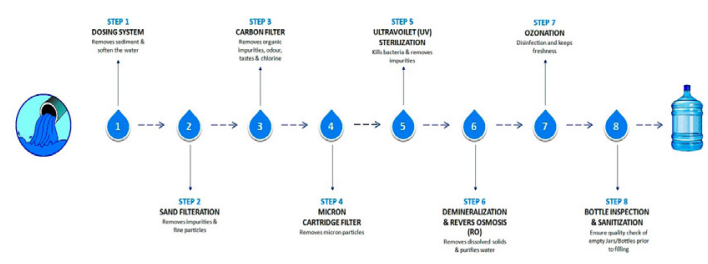

Figure 8: Schematic components for a drinking water treatment plant

(Source: https:/ / bookacan.com/waterpurification-Methods)

For 2000 liters/hr. production, an estimated cost of the plant would be NRs. 1,46,00,000.00 (Source: The Kathmandu Post, 2017) including the construction cost, equipment cost and operation cost.

\subsubsection{Irrigation}

To study the requirement of the irrigation facility, the crop being cultivated and its water requirement were studied. The simple cost analysis of the infrastructures was also carried out to see the economic justification of constructing the canals in the village area. In the study, the area was found to have low suitability for the cultivation. The crops like mustard, millet, buckwheat, maize, lintel etc. are cultivated in this area for subsistence. The water requirement for these crops is also very small. Hence, economic analysis for commercial irrigation was not done for this area.

The land suitability assessment can help to limit the maximum irrigable area for each reservoir. The dry season water budget, defined as the sum of the total dry season flow volume and reservoir's active storage volume, was used to define three different water allocation scenarios based on the water availability during the dry season.

\subsubsection{Flood Control}

To study the dams for the purpose of the flood control, the geo-morphometry of the catchment area as well as long term flow analysis for peak flood needs to be explored for the selected stream. However, for the small hydropower, small structures like weirs are constructed. These structures are designed to regulate the flow for the power generation in small hydro. Construction of weirs can decrease in the adverse effect of the immediate floods in the downstream. However, the proper flood control design requires peak flow analysis of the stream in the temporal variation. As, no flood was recorded till date in the given stream, flood control analysis was not done.

\subsubsection{Forestry}

Its main focus was to study the effect of the dam. The water collected on the upper portion of the dam forms an artificial lake that usually helps the local fish production and forest to densify due to the formation of swamps.

\subsubsection{Development of Industry and Employment Generation}

Industry development and employment generation should be analyzed for both direct 
and indirect beneficiaries. In the construction phases, many laborers and skilled technocrats get the direct benefit, and during its operation phases, a number of people get benefits, some as sociological changes, upliftment in living standards, and access to many physical infrastructures, etc.

\subsubsection{Recreation/Tourism}

With careful planning, hydroelectric developments may be relatively compatible with tourism in some circumstances. Although the time of research possibly reduces the applicability of the results in a boarder context, the planning and policy debates concerning the relationships between hydroelectric and other energy developments and tourism can be done on the project basis alone. Swimming, boating, fishing, camping, skiing, and hiking are just some of the recreational activities that take place year-round and across the country at sites developed and supported by the hydropower industry (NHA, 2020). Dam operators can work with local communities to allow for recreational access. Recreation related to water activities, local tour to the conserved areas, and local cultural activities integrated to tour operations and hotel business can harness the economy through internal and external tourism in the area.

\section{Results and Discussion}

The study was based on the feasibility of different facilities incorporating the hydropower project; individual analysis is necessary based on the priority list created after reconnaissance survey. Some of the major findings (result) of the prefeasibility study are as follows.

- The discharge for $45 \%$ exceedance in Padhu River would be $0.3 \mathrm{~m}^{3} / \mathrm{sec}$ (CAR
Method) with feasible potential of $1 \mathrm{MW}$.

- Fisheries: According to the annual progress report 2075/2076 of Directorate of Fisheries Development within the Ministry of Agricultural Development, the Nepal Agricultural Research Council (NARC), the fish productivity of Gandaki Province is 4.27 Metric tons/hectare of water surface. And the wet fish price $/ \mathrm{kg}$ varies from place to place, but Common carp, Rohu, Mrigal, Catla, and Grass Carp are sold at the rate of NRs. 300-450/kg (Husen, 2019). These are the typical fishes found in this region. Taking that reference, the gross return would be NRs. 14,94,500 and $\mathrm{B} / \mathrm{C}$ ratio 1.98 . This calculation clearly indicates the profitability of aquaculture in this region.

- Drinking water: As the immediate need for drinking water was not realized in the nearby village, the water could be bottled and supplied to the nearby market. If the plant is assumed to run 8 hours per day, with the average cost NRs. 5 per liter of water in jar and bottle, revenue generated would be NRs. 2,88,00,000.00 per year and $\mathrm{B} / \mathrm{C}$ ratio 1.97. This showed the economic feasibility of drinking water production.

- Irrigation: As the crop cultivation in the area was low, and the farming area was at a considerable distance from the streamline, the economic justification was inadequate. Similarly, the decreasing trend to cultivation in the hilly region and shifting to other commercial agricultural production discouraged the irrigation facility in the Padhu Khola.

- Employment Generation: For hydropower, it was determined that direct jobs ranged anywhere from 5 to 
6 FTE (Full Time Equivalent) per MW. FTE - representing one job for a full year (Rakesh, 2010). Hence, for this project 5-6 FTE can be estimated for employment in Hydropower. For drinking water plant, each plant averaged only around 24 employees (Food and Water Watch, 2008). And, for aquaculture, it was estimated that in 2003/2004 it employed about 58 000 people and benefited about 104000 people (FAO) in about 500,000 hectares available for fish farming in Nepal (Shrestha, 1999). Considering that each sq. $\mathrm{km}$ of aquaculture employs 208 persons.

- Flood Control: The information, above the catchment considered, was not sufficient to predict the suitability of the dams for the flood control. However, no evidence was recorded in the past that may trigger the likelihood of any type of flood in the given area.

- Navigation: As the stream has low discharge followed by the steep terrain, there was no possibility of navigation facility in the area.

- Forestry: The catchment with major coverage of forest area, and infrastructure build might impact the forest resources. However, the dam is supposed to assist the forest area in densifying.

- Recreation/Tourism: The breathtaking views and hospitable nature of people are the major attractions of tourism in this region. The area could be developed as a major tourist destination with proper planning.

\section{Conclusion}

Efforts made on hydropower development, focusing on multipurpose projects, could result in miraculous economic development together with sustainable use of resources. This study intended to assess whether the proposed hydropower at Padhu Khola could be upgraded to a multipurpose project or not. After the necessary desk study, a checklist was prepared for addressing the feasible services in the study location, and economic analysis was done for the prioritized services. The most feasible services to be added to the project were found out to be aquaculture, followed by drinking water plants with the B/C (BenefitCost) ratio of 1.98 and 1.97, respectively. In parallel, services like floriculture, tourism, and forestry could be developed. Irrigation and navigation were not considered to be feasible in the given location. Moreover, for the detailed design of the infrastructures, a feasibility study and detailed project study with cost estimation are recommended.

\section{Acknowledgment}

The authors would like to thank the administration, faculty and staff of the Pashchimanchal Campus for providing the water testing laboratory facility for this study. Authors are also thankful to Subhash Karki and Usha Baniya, BCE students of the campus, for their support on laboratory experiments.

\section{References}

Adhikari, D. (2006). Hydropower development in Nepal. Economic Review, 70-94.

Basnet, K., \& Acharya, D. (2019). Flood analysis at Ramghat, Pokhara, Nepal using HEC-RAS. Technical Journal, 1(1), 41-53. https://doi. org/10.3126/tj.v1i1.27591.

Basnet, K., Baniya, U., \& Karki, S. (2018). Comparative study of design discharge calculation approaches: A case study on Padhu Khola, Kaski, Nepal. Oodbodhan, A Journal of TUTA, Pashchimanchal Campus, 41-49. 
Buras, N. (1982). Multi-purpose storage systems: Objectives, conflicts, alternatives. Canadian Water Resources Journal. Retrieved from https://doi.org/10.4296/cwrj0702208.

Food \& Water Watch, June 2008, The Unbottled Truth About Bottled Water Jobs,www. foodandwaterwatch.org.

Fritz, J. J. (1984). Small and mini hydropower systems: Resource assessment and project feasibility. McGraw-Hill Book Company.

h t t p s : / / k a th m a n d u post.com / money/2017/08/26/govt-enters-drinkingwater-business.

https://www.hydro.org/waterpower/whyhydro/other-benefits/

International Hydropower Association. (2018). Hydropower status report. Retrieved fromhttps: / / www.hydropower.org/ publications/2018-hydropower-status-report.

Khadka, S. \& Basnet, K. (2019). Storm water management of Barahi Chowk area, Lakeside, Pokhara, Nepal using SWMM. Proceedings of $2^{\text {nd }}$ International Conference on Engineering $\mathcal{E}$ Technology, KEC Conference, 2 (1), 320-325.

Ministry of Water Resources. (2001). The hydropower development policy, 2001. His Majesty's Government of Nepal.

Ministry of Water Resources. (2003). Guidelines for study of hydropower projects. Ministry of Water Resources, Department of Electricity Development. Kathmandu: His Majesty's Goverment of Nepal.

Multipurpose Use of Hydropower Reservoirs. (2018). Retrieved from energypedia. info: https://energypedia.info/index. php?title=Multipurpose_Use_of Hydropower_Reservoirs\&oldid=143454 $\backslash$.
Rakesh Radhakrishan, (2010) Study: Hydropower Potential Could Create 1.4 million Jobs, October 2010, Hydro Review.

Safeworks Construction Nepal (SWCN). (2019). Detail desk study report of Padhu Khola small hydropower project (940KW). Kathmandu: Ministry of Energy, Department of Electricity Development (DoED).

Sharma, T., Dhakal S. C., Kattel, R.K., Gharti, K., \& Lamichhane, J. (2018) Economics of fish production at Chitwan district, Nepal. Journal of Agriculture and Natural Resources,1(1), 21-31.

Shrestha, J., (1999) Coldwater fish and fisheries in Nepal. Fish and fisheries at higher altitudes. Asia. FAO Fisheries Technical Paper. FAO, Rome, (385), pp.13-40.

Small Hydropower Promotion Project (SHPP/ GTZ); Mini-Grid Support Programme (MGSP/ AEPC-ESAP). (2004). Micro-hydropower design aids manual. Kathmandu.

Thapa, H. B. (2014). Hydropower development policy of Nepal: An overview of its implementation. Retrieved from http:/ / therisingnepal.org.np.

Using Hydro Power Plants for Flood Prevention. (2017, April 4). Retrieved from https://energypedia. info/index.php?title=Using_Hydro_Power_ Plants_for_Flood_Prevention\&oldid=203076. 